\title{
Author Correction: Multi-omics analysis of multiple missions to space reveal a theme of lipid dysregulation in mouse liver
}

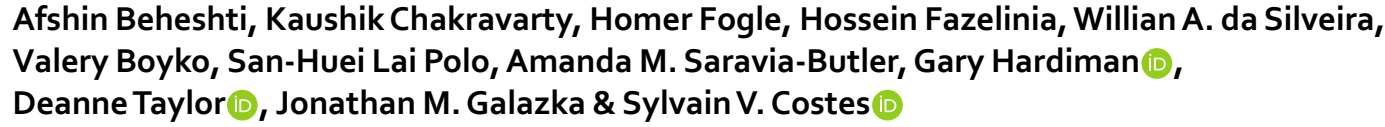

Correction to: Scientific Reports https://doi.org/10.1038/s41598-019-55869-2, published online 16 December 2019

In the original version of this Article, Hossein Fazelinia was incorrectly affiliated with 'Department of Biomedical and Health Informatics, The Children's Hospital of Philadelphia, Philadelphia, USA; Center for Mitochondrial and Epigenomic Medicine, The Children's Hospital of Philadelphia, Philadelphia, USA'. In addition, Deanne Taylor was incorrectly affiliated with 'twoXAR Inc, Mountain View, CA, USA'. The correct affiliations are listed below.

\section{Hossein Fazelinia:}

Protein and Proteomics Core Facility, and the Department of Biomedical and Health Informatics, The Children's Hospital of Philadelphia, Philadelphia, PA 19104, USA

Deanne Taylor:

Department of Biomedical and Health Informatics, The Children's Hospital of Philadelphia, and the Department of Pediatrics, The University of Pennsylvania Perelman School of Medicine, Philadelphia, PA 19104, USA

These errors have now been corrected in the PDF and HTML versions of the Article.

(c) (i) Open Access This article is licensed under a Creative Commons Attribution 4.0 International License, which permits use, sharing, adaptation, distribution and reproduction in any medium or format, as long as you give appropriate credit to the original author(s) and the source, provide a link to the Creative Commons license, and indicate if changes were made. The images or other third party material in this article are included in the article's Creative Commons license, unless indicated otherwise in a credit line to the material. If material is not included in the article's Creative Commons license and your intended use is not permitted by statutory regulation or exceeds the permitted use, you will need to obtain permission directly from the copyright holder. To view a copy of this license, visit http://creativecommons.org/licenses/by/4.0/.

(c) The Author(s) 2020 